\title{
The Strategy of Traffic Safety in Bosnia and Herzegovina - Police Aspects
}

OSMAN S. LINDOV, University of Sarajevo,

Faculty of Traffic and Communications, Sarajevo, Bosnia and Herzegovina

SAMIR A. ČAUŠEVIĆ, University of Sarajevo, Bosnia and Herzegovina

Faculty of Traffic and Communications, Sarajevo

ŠEFKIJA N. ČEKIĆ, University of Sarajevo,

Faculty of Traffic and Communications, Sarajevo, Bosnia and Herzegovina

This paper presents a strategy and action plan was implemented in the Federation of Bosnia and Herzegovina within the Ministry of Interior within 5 years. Given are the steps to achieve the strategic objectives.

Key words: strategy, road safety, police aspects

\section{INTRODUCTION}

Baseline Road traffic safety strategy in Bosnia and Herzegovina (2008th-2013th) were conducted on the proposal of the Federal Ministry of the internal affairs, which was accepted by the Government of the Federation of Bosnia and Herzegovina and arising from the need to professionally investigate and determine the conditions and factors encouraging the place and role of the safety of road transport of Bosnia and Herzegovina, actually the Federation of Bosnia and Herzegovina.

Road traffic in Bosnia and Herzegovina is regulated at the state and entity levels, and with the adoption of a state law on traffic safety on roads in Bosnia and Herzegovina, this segment of traffic needs to be defined and implemented at the national level is certainly supported entity institutions (Ministries of Transport, Ministry of internal Affairs, Ministry of Education, Ministry of Health, Directorate of roads / road, etc.).

The main objective of the subject and purpose of the starting points for the of road transport safety strategy in Bosnia and Herzegovina (2008th-2013th) was, using appropriate research methods, to provide the necessary quantitative and qualitative identification of a complex system of road transport safety. Decisive reason for this approach is the fact that the traffic safety

Author's address: Osman Lindov, University of Sarajevo, Faculty of Traffic and Communications, Sarajevo, Zmaja od Bosne 8

Paper received: 13.11.2014.

Paper accepted: 24.11.2014. system in Bosnia and Herzegovina, pending state legislation and writing strategies at the entity level, in terms of programming and development base unexplored in the current environment and as such is not fully determined.

\section{WHY STRATEGY AND WHY THE POLICE IN ROAD SAFETY}

In addition, very aware of the difficult situation, constantly growing number of deaths, especially among young people, on the one hand, and the fact that the traffic safety under the jurisdiction of cantons which (geographically limited, with partial and time-limited access) are not able to achieve individually significant results the entire territory of Federation of $\mathrm{BiH}$, the Federal Ministry of Internal Affairs has decided to launch an initiative to elaborate a strategic document to the application of appropriate research methods, to provide the necessary quantitative and qualitative identification of the complex system of road transport safety, and to propose measures that will enable the resolution of a number of causes of traffic accidents [1].

For this reason, the Federal Ministry of Internal Affairs has established a commission made up of reputable experts in the traffic safety and representatives of the Ministries of Internal Affairs, which is in record time, at the end of January 2008 completed this document, which was adopted by the Government of the Federation at its session in 28th February 2008.

In addition, since the establishment of the Commission in July 2007, the one of the main motives of creation such conceived research document with clearly defined objectives and measures, was that the 
institutions at the level of Bosnia and Herzegovina, offer a starting point for the development and implementation of the Action plan of Bosnia and Herzegovina, whose implementation would achieve the intended goals. For this reason, at the initiative of FMI, the Government of the Federation submitted a document Baseline of road transport safety strategy 20082013 to the Council of Ministers of Bosnia and Herzegovina.

But in the absence of any activity at the state level and proceeding from the fact that the official statistics showed a constant tendency to increase the number of killed and seriously injured in traffic on the one hand, and the goals set in the strategy document and the Action Plan by the Minister of Internal Affairs has formed a team of experts for the realization of these operations starting work 5.52008 year, which consisted of seven members, in April 2012 was supplemented with 6 members, the Minister's decision of the Federal Ministry of the internal affairs.

For the realization of these operations, it was necessary to bring the Action Plan at the level of the Federal Ministry of the internal affairs , and action plans cantonal ministries of Internal Affairs, then the action plans of the federal ministry of transport and communications, health and education, which was conducted during 2008 year.

In the first half of the 2008 was signed the Action Plan to implementation of the document Baseline of road transport safety strategy $2008-2013$ by the Federal and all 10 of Cantonal Ministers of Internal Affairs and the Director of the Federal Police Administration and all 10 police commissioners. Signing of this document, we began the implementation of the project by the police structures that are in the period of the implementation of this document showed that strategically designed and coordinated the work on the field so they can achieve and exceed expected results [2].

Also, it was necessary to bring an Instruction on Mutual Information between the Federal and Cantonal Ministries of Interior, which is also done and signed by all of the Cantonal Ministers of 2008 year. This directive is precisely defined manner and content of communication between of the Federal Ministry of the internal affairs police and Cantonal Ministries of Interior in the field of traffic safety.

During the five years of work, instruction is again supplemented and showed all their necessity and expediency of its adoption for accurate and timely information Cantonal Ministry of police on the state of traffic safety, in order to analyze trends in this area.

The tasks set out in the Strategy and Action Plan also demanded the establishment of a central database in the Federal Ministry of Internal Affairs for monitoring, statistical processing, analyzing and making recommendations to the competent entities for traffic safety. This database has been established in cooperation with the Directorate of motorways of Federation $\mathrm{BiH}$ and with the expert help of Faculty of Traffic and Communication in Sarajevo.

On the basis of the above, it was established the legal and action framework for the operations of the Expert Team and other subjects as co-holder of this project.

In this manner, through one year of preparation and research platform of creating a strategic document, five years of implementation of the Action Plan, using all the capacity of local institutions, the work of the Expert Team FMI and excellent cooperation and the work of the Federal and Cantonal Ministries of Internal Affairs, has aproved to be very successful and effective, which led to the realization of most of the objectives set.

\section{THE TREND OF MOVEMENTS OF TRAFFIC ACCIDENTS 2002-2008.}

Figures 1 shows the trend of traffic accidents in the period 2002nd to $2008^{\text {th }}[3]$.

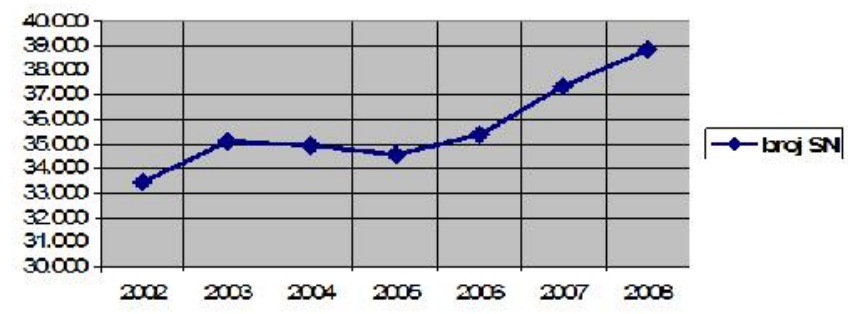

Figure 1 - Trend of traffic accidents in the period 2002nd to 2008th

\section{HOW TO REACH THE GOAL ?}

Figures 2. shows Front Page and Content of the Strategy 2008-2013.

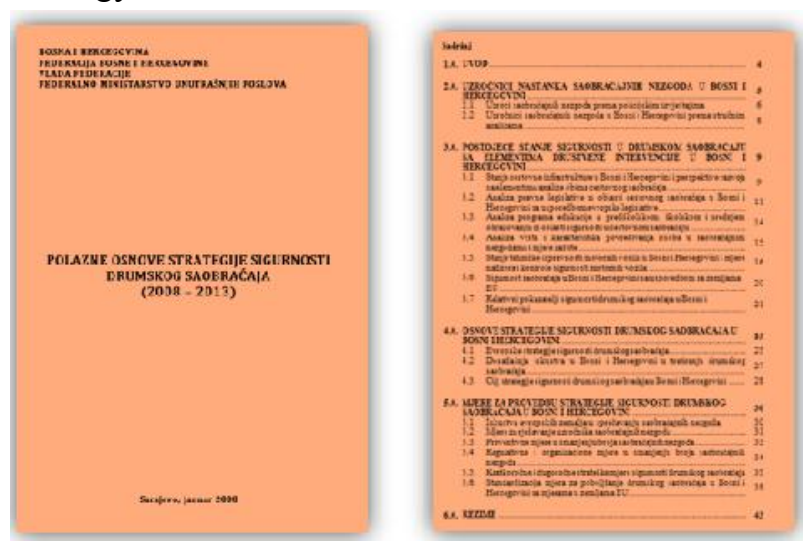

Figure 2 - Front Page and Content of the Strategy 2008-2013. 
Figures 3 shows Front Page and contents of the Action Plan 2008-2013

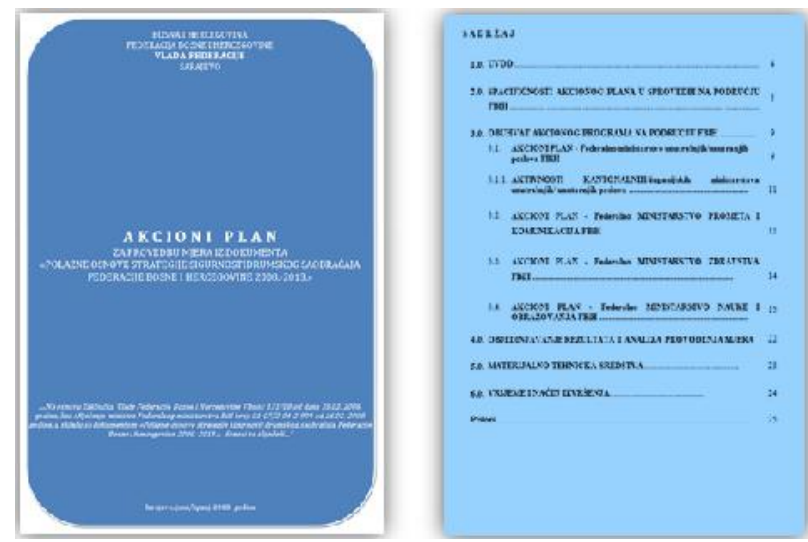

Figure 3 - Front Page and contents of the Action Plan 2008-2013

\section{MAIN GOALS AND RESULTS}

Goal number 1: Reduce the number of deaths by $30 \%$. Result: Reduced the number of deaths by $35.5 \%$. Saved 419 lives of citizens.

Goal number 2: Reduce the number of seriously injured by $30 \%$. Result: Reduced the number of seriously injured by $43.3 \%$. Number of people who sustained serious injuries in traffic is less for 2,774.

Goal number 3: Reduce the number of accidents by $30 \%$. Result: Reduced the number of traffic accidents by $19.85 \%$. There's been 26,792 less traffic accidents

\section{ACTIVITIES OF AN EXPERT TEAM - HOW HAS ACHIEVED THE OBJECTIVE?}

Figures 4 shows Media campaigns in cooperation with Cantonal Ministry of Police „WATCH HOW YOU'RE DRIVING““.

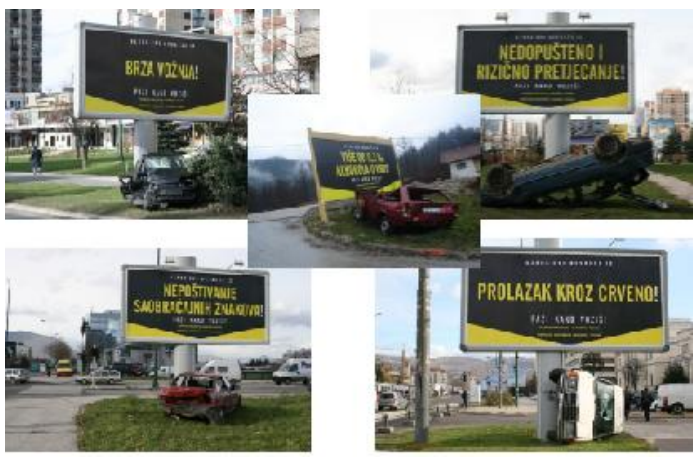

Figure 4 - Media campaigns in cooperation with Cantonal Ministry of Police ,WATCH HOW YOU'RE DRIVING “

Figures 5 shows Media campaigns in cooperation with Cantonal Ministry of Police "LOVES LIFE RESPECT RULES”.

Figures 6 shows Media campaigns in cooperation with Cantonal Ministry of Police "CAREFUL WHAT TRACK LEAVING.
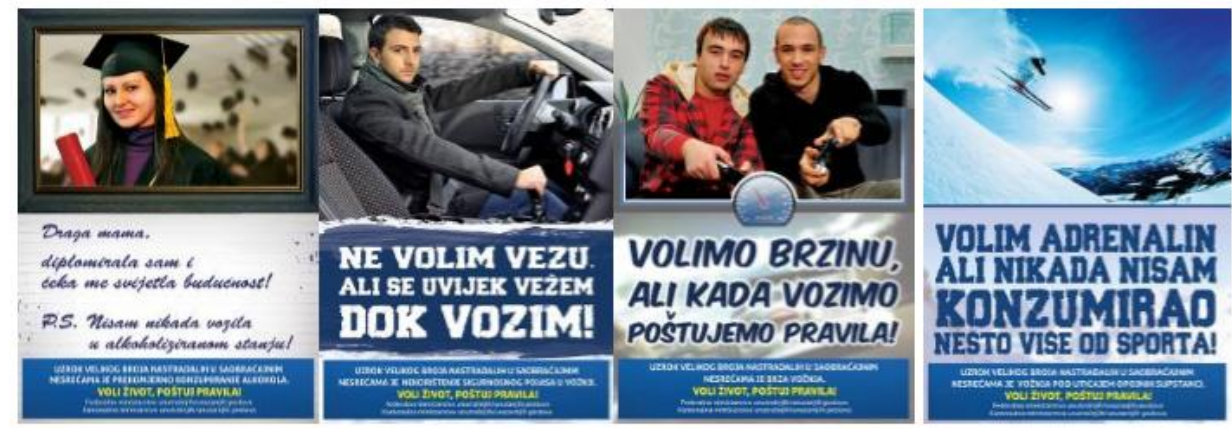

Figure 5 - Media campaigns in cooperation with Cantonal Ministry of Police “LOVES LIFE RESPECT RULES”.
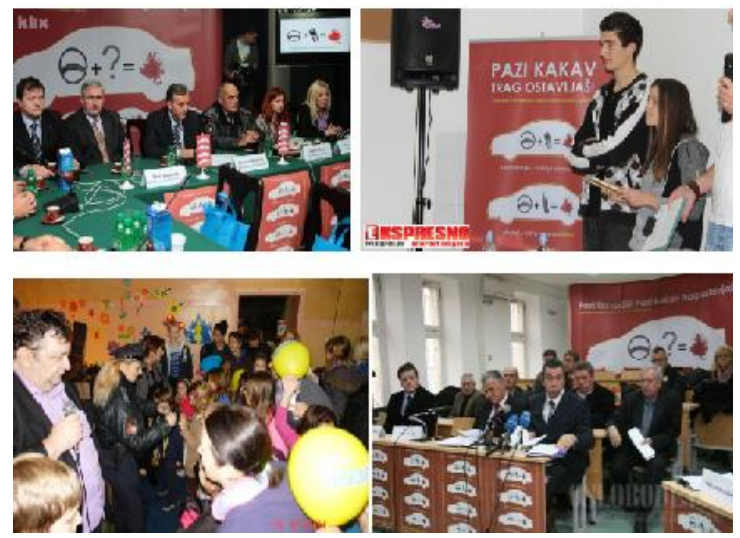

Figure 6 - Media campaigns in cooperation with Cantonal Ministry of Police "CAREFUL WHAT TRACK LEAVING 

ople.

Figures 7 shows Survey and testing of young pe-
Figures 8 shows Round tableswith photos and themes.
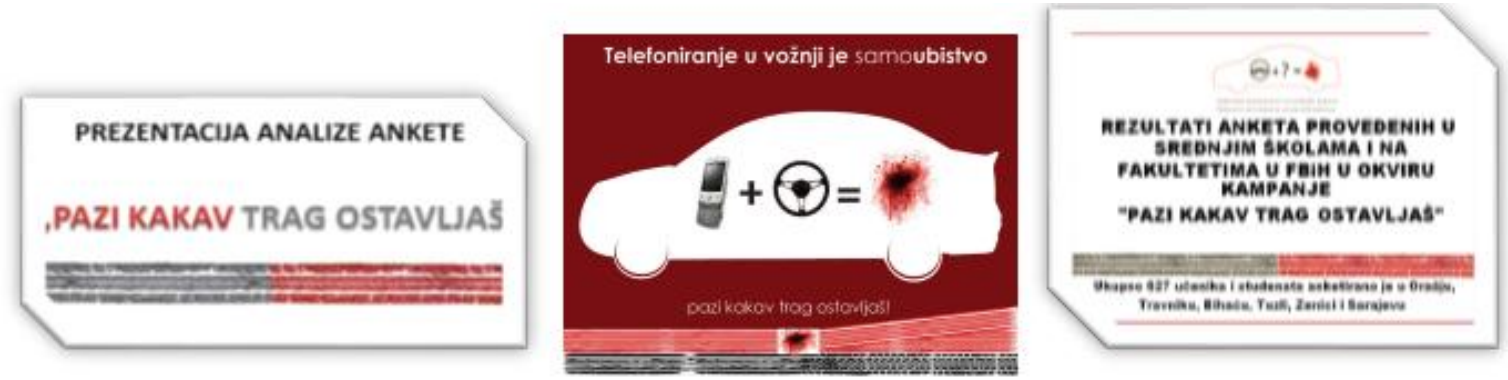

Figure 7 - Survey and testing of young people.
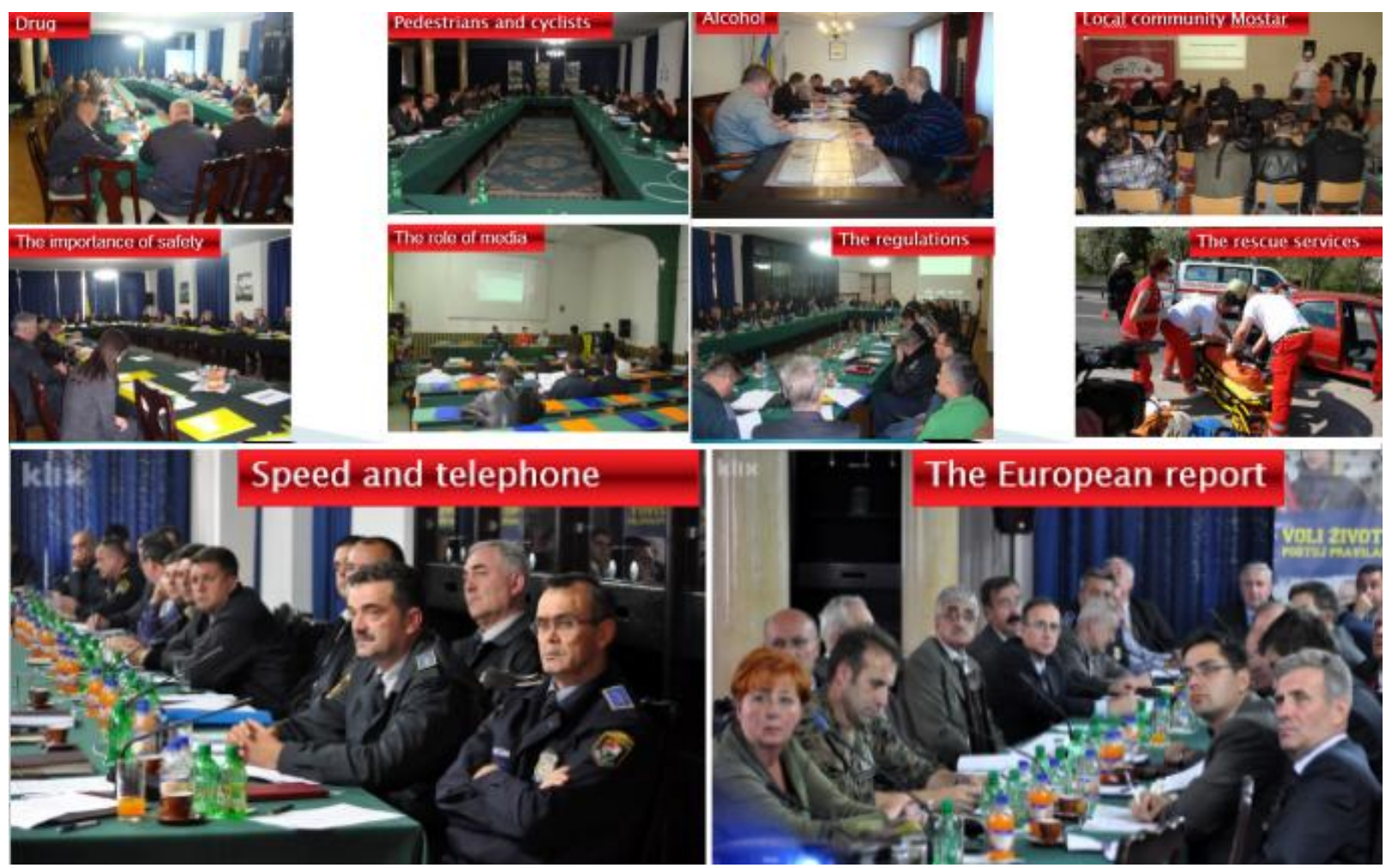

Figure 8 - Round tableswith photos and themes

Figures 9 shows marking "Weeks of global road safety and the UN decade".

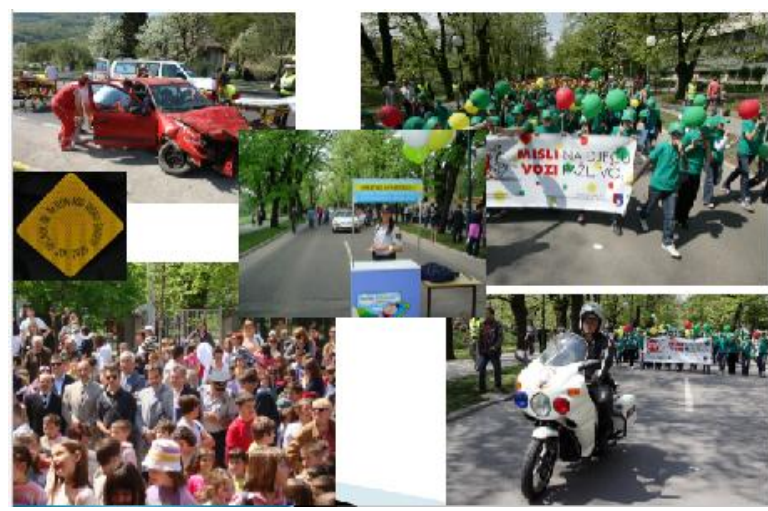

Figure 9 - Marking "Weeks of global road safety and the UN decade"
Figures 10 shows Front Page "Database on road accidents"

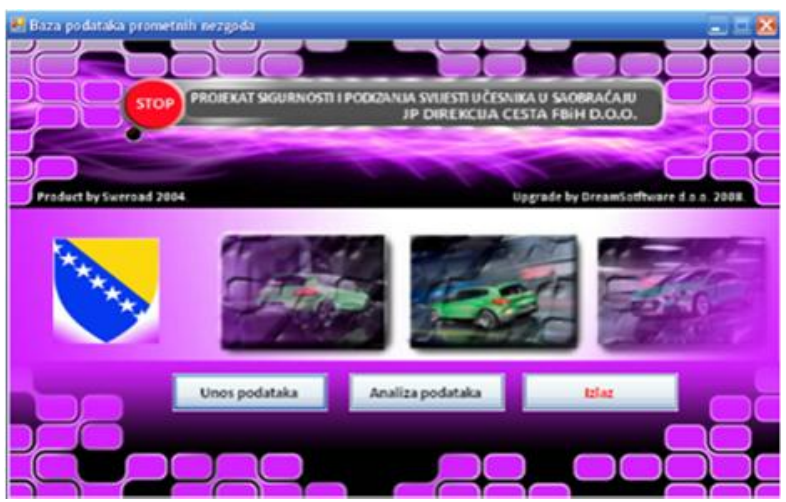

Figure 10 - Front Page "Database on road accidents" 
Figures 11 shows a few pictures participation in NATO "Open days of safety". Figures 12 showscover

pageLecture at universities in $\mathrm{FBiH}$ "Youth and traffic safety".

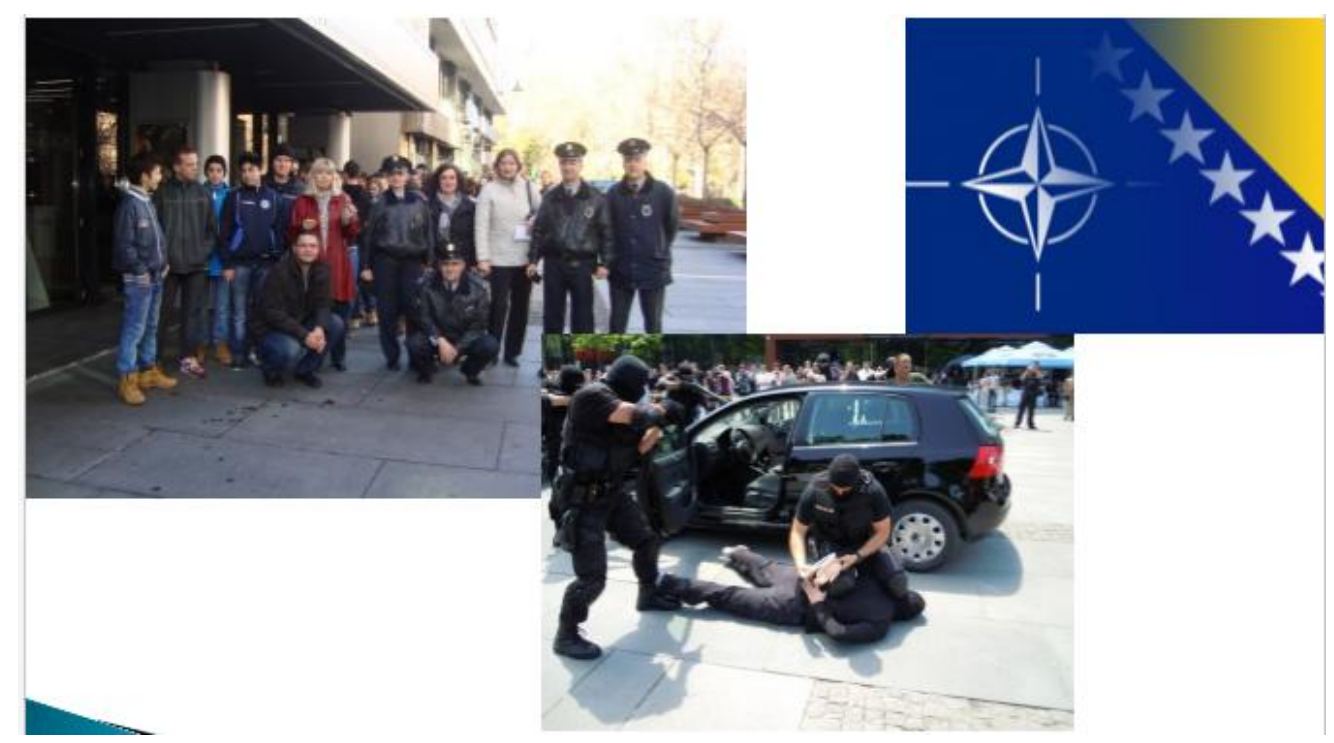

Figure 11 - NATO "Open days of safety".
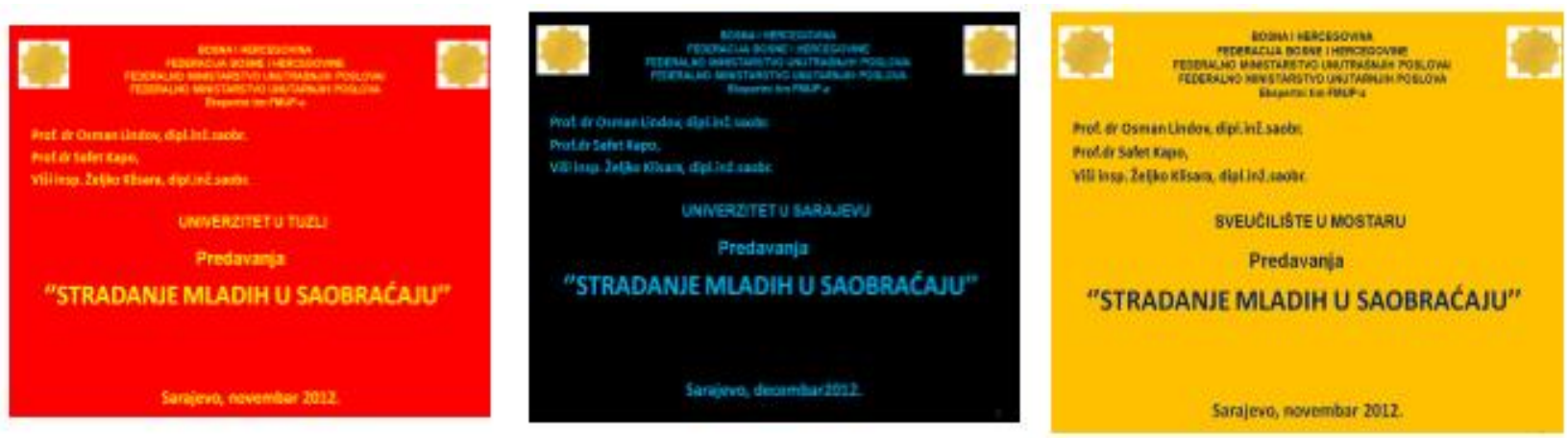

Figure 12 - Cover page Lecture at universities in FBiH "Youth and traffic safety".

Procurement of equipment for the cantonal MIAs: Stationary radars for cantonal MIAs; Equipment for the detection of narcotics for cantonal MIAs; Mobile radars for cantonal MIAs; Computers for cantonal MIAs and etc...

\section{PREVENTIVE POLICE MEASURES}

Preventive police measuresin four years expressed in numbers are: 2,893 meetings with the directors of primary schools and teachers; 11,943 contacts with the media; 525 meetings with representatives of the driving school and the committee for taking the driving test; 609 meetings with municipal courts - judges of misdemeanor; 5,755 contacts with the other institutions which are related to traffic safety (axle load control, etc.); 8,379 training police officers about communicating with participants in traffic.

Sanctioned:exceeding the speed of motor vehicles in 708,050 cases; driving under the influence of alcohol in 81,461 cases; driving under the influence of alcohol in 81,461 cases; driving under the influence of drugs and other intoxicating substances in 57 cases; improperly overtaking in 29,130 cases; non-compliance with traffic light signals in 13,570 cases; driving without having passed a driving test in the 19,931 cases; using a mobile phone while driving a motor vehicle in the 25,438 cases.

Managing an unregistered vehicle in 46,544 cases; non-use of seatbelt and helmets in 113,312 cases; technical failure and the number of vehicles sent to the extraordinary technical examination in 7,417 cases; 7,514 offenses committed by pedestrians; 11,438 cases of non-compliance with obligations driver to pedestrians[3].

\section{THE TREND OF MOVEMENTS OF TRAFFIC ACCIDENTS2008 - 2013}

Figures 13 showsTrends in the number of traffic accidents 2008 - 2013 goals and achievements. 


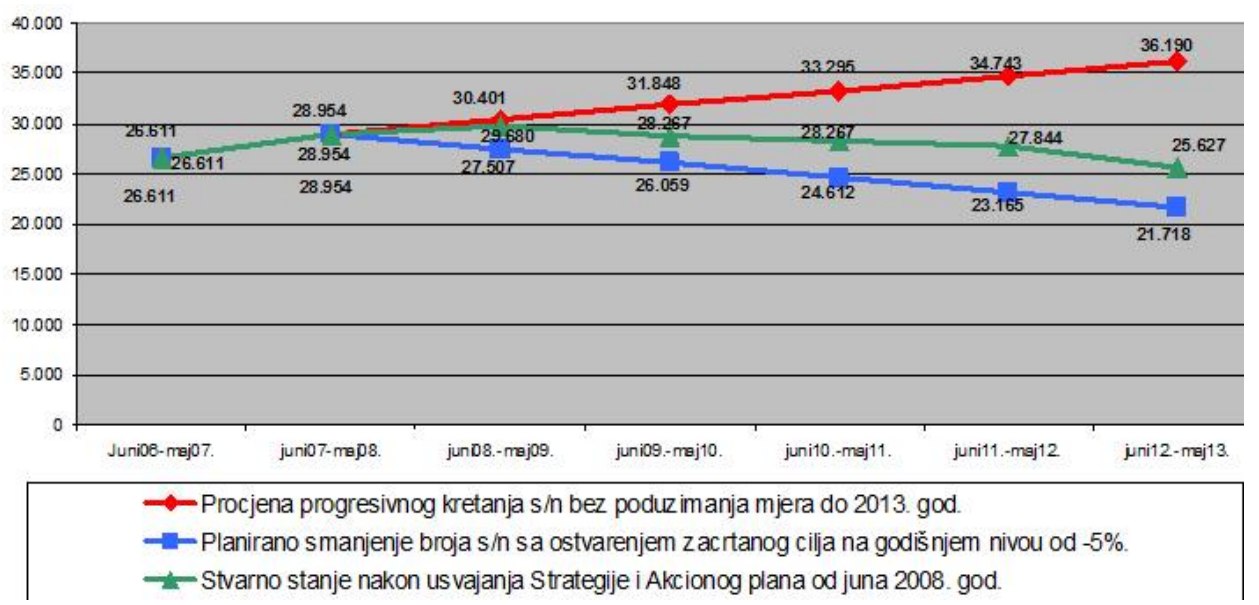

Figure 13 - Trends in the number of traffic accidents 2008 - 2013 goals and achievements.

Figures 14 showsTrends in the number of fatalities showsTrends in the number of seriously injured 2008.2008 - 2013 goal and achievements. Figures 15 2013. goal and achievements.

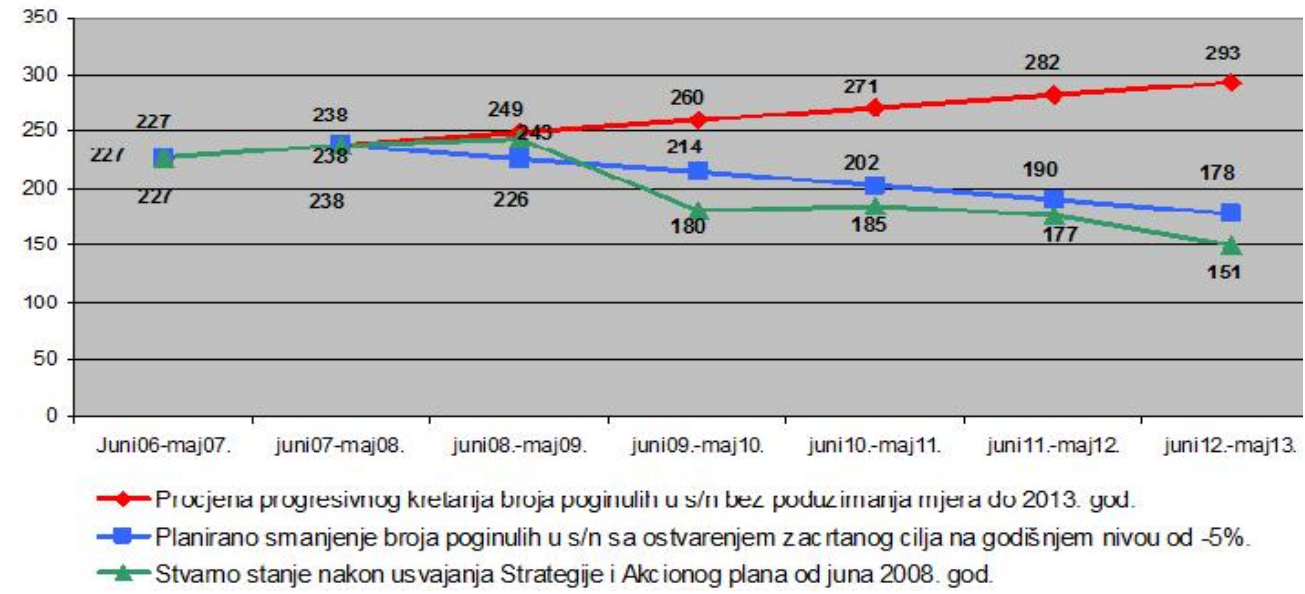

Figure 14 - Trends in the number of fatalities 2008 - 2013 goal and achievements

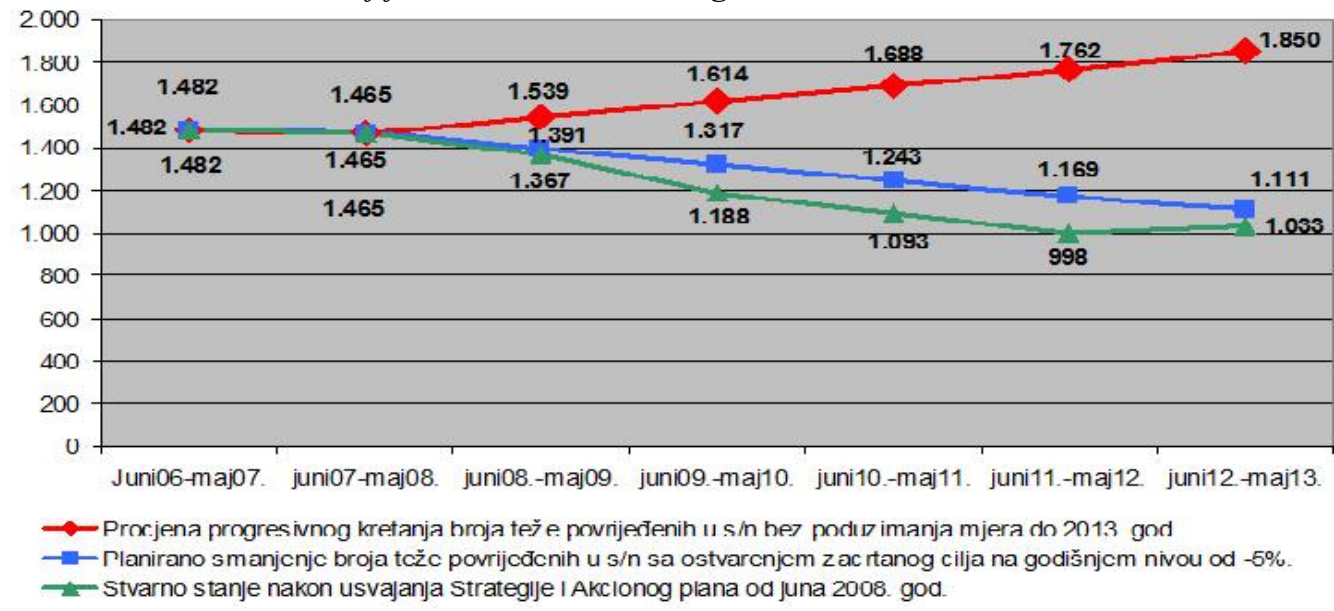

Figure 15 - Trends in the number of seriously injured 2008.- 2013. goal and achievements.

\section{CONCLUSION}

Saved 436 lives in five years. 2,774 people are not serious bodily injury. It did not happen 26792 traffic accidents. Enormous financial savings.
We want to save more lives and engage in the UN Decade (decade) security from 2011 to 2020 , which the United Nations has committed all UN member states to "fight" to increase the level of traffic safety. 
Message to the citizens: "watch the way you drive your car, bicycle, motorbike or how you behave as a pedestrian"; "love life and obey traffic laws because they save your or your child's life"; "be carefull what trail you are leave in traffic - do not let it be blody trail"

\section{REFERENCES}

[1] Polazne osnove strategije sigurnosti drumskog saobraćaja (2008-2013), Federacija Bosne I Hercegovine, Sarajevo, januar 2008.

[2] Akcioni plan za provedbu mjera iz dokumenta «Polazne osnove strategije sigurnosti drumskog saobraćaja Federacije Bosne I Hercegovine 2008-2013.,
Bosna i Hercegovina, Federacija Bosne i Hercegovine, Vlada Federacije, Sarajevo, juni/lipanj 2008. godine

[3] Analysis of causes and consequences of trafficaccidents for the period june 2009 to may 2010 in the Federation of Bosnia and Herzegovina, (The analysis was made on the basis of police reports of the cantonal Ministries of Internal Affairs), Bosnia And Herzegovina, Federation Of Bosnia And Herzegovina, FederationMinistry Of Internal Affairs, Expert team for analysis and coordination of implementation of measures under the Action Plan for enforcement taken from the document "Initial Basic Strategy for Road Traffic Safety 2008-2013" ,Sarajevo, December 2010 .

\section{REZIME}

\section{STRATEGIJA BEZBJEDNOSTI SAOBRAĆAJA U BOSNI I HERCEGOVINI - POLICIJSKI ASPEKT}

U radu je predstavljena strategija bezbjednosti i akcijski plan bezbjednosti u saobraćaju koji je sproveden u Federaciji Bosne i Hercegovine u okviru Ministarstva unutarnjih poslova u roku od 5 godina. Prikazani su koraci u postizanju strateških ciljeva.

Ključne riječi: strategija, bezbjednost u saobraćaju, policijski aspekt bezbjednosti u saobraćaju 